\title{
前言：Covid-19 疫情的倫理反思
}

\section{Introduction : Ethical Reflections}

\section{on the Covid-19 Pandemic}

\author{
張 穎
}

\section{Ellen Y. Zhang}

自去年 12 月以來在全球爆發的 Covid-19 疫情, 已經徹底改 變了世界的格局和走向。疫情不僅打亂了普通人的生活節奏, 也 給整個世界帶來了不確定的因素。我們看到, 突飛猛進的科學技 術沒有改變人類面對突發盒疫時的脆弱與無助。與此同時, 如何 看待公共疫情和公共衛生, 再次成為人們關注的重點。本期就中 國這次面對疫情所引發的種種醫學和生命倫理學議題進行分析與 探究。文章作者來自中國內地、香港和台灣, 他們從不同的角度, 對此次疫情所引發的倫理問題提出自己的意見。

〈疫區、口罩與無症狀感染者——新型冠狀病毒疫情如何破 壞了我們的公共生活〉一文指出, 疫情的突發打破了社會原有的 熟悉與信賴的人際關係, 人們不得不在發現作為患者的 “他者” 的基礎上, 重新確立自己的家庭生活和公共生活。由於目前缺乏

\footnotetext{
張 穎, 香港浸會大學應用倫理學研究中心主任、宗教及哲學系系主任及副教授, 中國香港。

Ellen Y. Zhang, Director, Centre for Applied Ethics; Head and Associate Professor, Department of Religion and Philosophy; Hong Kong Baptist University, Hong Kong, China.
}

《中外醫學哲學》XVIII:1 (2020 年) : 頁 1-4。

International Journal of Chinese \& Comparative Philosophy of Medicine XVIII:1 (2020), pp. 1-4.

(c) Copyright 2020 by Global Scholarly Publications. 
科學的檢測手段, 人們往往採取簡單粗暴的方式進行把人進行分 類, 其中包括口罩標籤的使用。口罩的使用成為人們在混亂的疫 情中找到群體邊界和歸屬感的捷徑。然而, 在群體的重新組合中, 想像的 “敵人” 被創造出來, 並因此引發一系列的倫理問題, 即 如何處理瘟疫下的人際關係。中國或西方的傳統道德哲學是否可 以解決這些問題呢? 作者認為, 群體的區分以及重新組合, 是為 了確定有效的自我保護的機制。但在庽害關係的考量之外，還應 存在著對他人以及公共生活的普遍義務。而這種高於自我保護的 道德義務, 或許是我們能夠戰勝疫情的真正希望所在。

〈新冠肺炎病毒疫情中的仁道 : 從文化與倫理看病毒疫情之 啟示〉一文指出, 病毒的特性與人類某些行為極為相似, 而且病 毒與人類起源實有不可分割的關係。譬如人類出於原始生存的欲 望, 以暴力的方式宰控一個地方和地域的人群。病毒雖然不是一 個生命體, 但卻具有複製或繁殖的能力。而它的負面表現在它由 宿主取得繁殖的資源之後會殺害宿主。作者從倫理與文化, 特別 是儒家的精神, 檢討我們與此病毒共存時, 如何調整我們的生活 與價值, 建立生命共同體的觀念, 以減輕或免除由此嚴峻疫情所 受到的個人與社會的創傷和後遺症。本文分析了在地球村的緊密 關係之下, 我們必須保持有效的防疫工作之下才可以開封和進行 經濟生產、物品流通, 否則會在目前和日後不斷發生重覆的社區 感染。人類必須團結互助、共同承擔和接受各種不便, 互讓互諒、 助人助己, 才能夠平安渡過此一巨大災難。

〈疫情背景下對待無症狀感染者的道德困境與出路探究〉主 要處理在對待無症狀患者時面臨的道德困境, 譬如, 如何採取相 應的措施? 如何對所採取的措施進行事實性的描述? 所採取的措 施會有哪些隱藏的問題? 這些問題給我們帶來哪些倫理思考? 作 者指出, 對於無症狀感染者, 既要嚴格控制, 又要尊重和關懷。 而不是出於求生的恐懼, 對他們進行侮辱和歧視。文章作者認為, 倫理學的核心問題是對於某種行為的正當性找到充分的理由。但 
是在處理無症狀感染者這一問題上, 無論是政府、社群、或個人 的某些行為, 都很難從倫理學上給予支持。作者指出, 中國內地 的道德論述, 很多還是流於教科書上的論述。而在實際的道德選 擇中, 我們卻無法處理道德困境的具體挑戰。

〈新冠盒疫蔓延時的「知情同意」原則〉一文就此次爆發的 新冠病毒瘟疫, 探討中國在對抗疫情過程中所帶出的與知情同意 相關的倫理議題。根據世界衛生組織的規定, 「知情同意」意指 有行為能力的個體根據充分的相關信息採取行動的主動權, 這個 行動不能受到強制或誘導。然而在疫情突發時期, 知情同意所涵 蓋的諸如知情、能力、自願等原則在公共衛生受到挑戰之時也會 受到一定的限制。如何在個人自主、個人權利與公共衛生、公共 利益之間找到平衡? 如何在最低限度的道德言語中找到共同的道 德原則, 這是疫情中值得探討的倫理議題。本文從世衛《傳染爆 發倫理問題指南》出發, 對其具體的倫理原則進行分析, 並將其 原則放在此次爆發的疫情情境中加以説明, 创析這些原則在具體 操作上的道德困境。作者最後試圖從儒家倫理學的角度㘓述如何 在東方的「家長主義式干預」和西方的「個體自主式不干預」中 找到合適的平衡點, 如何在保護公民自由和權利與保證公共衛生 和公善中找到平衡點。

〈2019冠狀病毒病疫情下的道德議題的初步哲學探索〉一文 提出, 在此次冠狀病毒病疫情之下, 至少有兩個公共衛生政策的 道德議題變得異常重要。第一, 現時有不少爭議是關於這些抗疫 政策與個人自由的衝突。這是很典型的公共善與個人自由衝突的 道德爭論, 但疫情令這樣的衝突成為直接而迫切的顧慮。第二, 這個世界在疫情之前已有很多嚴重的不平等問題, 但現在有些防 疫政策令社會的不平等變得更為嚴重。就這兩個問題, 作者不是 純粹地使用權利的進路, 而是以阿馬蒂亞 - 森的後果評價和能力 進路作為道德推論和基礎。作者認為, 後果評價和能力進路這兩 
個由森提出的理念可以把不同的道德理論和傳統與公共衛生議題 連繫起來。

〈如何平衡治理效率與隱私保護? 中國和新加坡新冠病毒接 觸者追蹤應用程式隱私政策的文本分析〉是本刊唯一涵蓋實證的 公共政策研究的論文。作者指出, 新冠病毒疫情催生了以中國大 陸的 “健康碼” 和新加坡的 “TraceTogether” 為代表的接觸者追 蹤應用程序的看法的使用。與此同時, 如何利用人工智能的技術, 在大數據治理中平衡效率和個人隱私的關係, 成為使用數碼追蹤 技術國家所遭遇的共同的倫理問題。就中國與新加坡而言, 兩國 的法律都規定, 在收集個人信息之前必須向個人信息的具體明確 告知所收集的信息類型、使用信息的規則, 並獲得信息主體的授 權同意。透過對 “健康碼” 和 “TraceTogether” 的比較研究, 作 者發現, “健康碼”在應用上可以有效的幫助防控疫情, 但收集 的個人信息範圍廣, 儲存時間不明確, 而且隱私政策內容含糊。 相比之下，“TraceTogether”對收集的個人信息範圍有所限制， 儲存時間明確, 隱私政策內容透明。這兩種大數據的運用模式説 明, 風險管控需要平衡公共利益和個人權利, 這是倫理學的邊界。

上述六篇文章, 皆從不同的側面, 探討個人權利與公共安全 的平衡問題, 這是我們遭遇任何疫情時不能避免的問題。的確, 在公共衛生的問題上, 我們需要建立生命共同體的觀念, 即便是 傳統的自由主義者, 也不會在疫情中否定生命共同體的意義。由 於本刊篇幅的限制, 有關應對疫情的其他倫理和法律的問題不能 一一涉及。 